\title{
The College Core: Why A Valuable Curricular Component Can Be A Challenge To The Provision Of Services That Enhance School Of Business Student Outcomes
}

\author{
Thomas J. Kopp, Siena College, USA
}

Joseph L. Rosetti, Siena College, USA

\begin{abstract}
Out-of-class faculty services, such as advising, career advice, and lecture series, stimulate student interest, retention, and graduation rates. Through modeling the interrelationships between the allocation of faculty lines and a college's general education core requirements, its impact on the provision of out-of-class faculty services is explored. The results indicate that a professional school's undergraduate students will have less access to these services relative to their liberal arts peers. In addition, data envelopment analysis is applied to support the notion that the higher satisfaction often expressed by liberal arts students is not necessarily an accurate indicator of the relative quality of the services being provided by the various schools of the college but rather the resources dedicated to the provision of faculty out-of-class services.
\end{abstract}

Keywords: Advising; Core Curriculum; Faculty Allocation

\section{INTRODUCTION}

$\mathscr{Q}$ ndergraduate education is in the midst of radical changes. Beginning in the 1980's, colleges were faced with shrinking numbers of potential students (Brocklehurst, 1980). Given this situation, the traditional model where students entered the college and then migrated to programs based on interest and availability was no longer viable. In the past, some students were forced to either select majors that were not their first choice or transfer out of the college. However, as the number of potential applicants declined, colleges began to model themselves as service organizations, as a way reduce such attrition (Slaughter \& Rhoades, 2004). This focus motivated enrollment administrators to adopt the perspectives of the field of service marketing (Gruber, Reppel \& Voss, 2010), further moving higher education to meet the "needs" of students, by shifting control over the educational process to the student customer. One significant innovation was the adoption of demand-based scheduling, where student demand is allowed to alter the college's mix of programs (Kopp \& Rosetti, 2009). Once adopted, demand-based scheduling drives both course offerings and the hiring of new faculty to teach within the programs where demand is rising. This has a subtle, but profound, impact on the provision of out-of-class services.

In addition to motivating the adoption of demand-based scheduling, the "student as customer model" suggests that in such a highly competitive environment, the college must offer services that engage students. While the core service of the college currently remains a classroom learning experience, the success of that key-stone experience requires interaction with supplementary services designed to enhance the overall college experience of the student. The unique challenge faced in providing these supplementary services is that they are often identified as "hygiene services" which means that they do not contribute to satisfaction among students but can cause dissatisfaction when the needs delivered by them are not met (Ng \& Forbes, 2009). While some of these services, such as student social clubs, may exist solely to offer students recreation, and social diversions, research has demonstrated that a critical part of a college's educational mission occurs outside the classroom (Astin, 1984, \& Pascarella, 1980). In response, services such as advising, travel, lecture series, career counseling and service 
activities are being used to directly promote academic success and student satisfaction (Byrd, 1994; Karrenbrock 2001; Belcheir, 2000). While such services enhance retention, four-year graduation rates, and learning outcomes, they also enhance the college's image, since these measures are used by both accrediting bodies and publishers of college rankings (Glennen, 1975; Glennen, Farren, \& Vowell, 1996).

This paper focuses on modeling the quantity of faculty resources available to be dedicated to the provision of such services in each of the college's schools. It examines how the adoption of demand-based scheduling and staffing in an environment that continues to recognize the value of a liberal arts core curriculum, unexpectedly distorts the ability to provide student-centered services. It also examines how some measures used to evaluate these services may be misleading those who are attempting to improve student satisfaction. While the analysis presented is modeled relative to a college with two schools, the results are applicable to any college with a general education requirement that resides predominately within any one school.

\section{The Problem At Diploma U}

Diploma $\mathrm{U}$ is a simple thought experiment designed to help visualize the impact that demand-based hiring has on the availability of faculty-provided services. Assume there is a University where six credits - a 3-credit general education requirement and a 3-credit school specific degree requirement - is all that is necessary to graduate. Also assume that the ten students who are enrolled at Diploma U select majors which evenly disperse them between the college's two schools - liberal arts and professional studies. Since course offerings at Diploma U are demandbased, faculty must be hired to meet student demand.

Because the general education requirement resides in the school of liberal arts, each liberal arts major will take six such credits to graduate while each professional studies student will take three liberal arts credits and three professional studies credits. If the college chooses to maintain a target level of academic intensity within all its schools, it will hire faculty to keep the number of student credit hours per faculty member equal across the schools. Therefore, the liberal arts school will hire for 45 total credit hours ( 15 for major requirements and 30 for the general education requirement) while the professional school will hire for the 15 credit hours taught.

This results in liberal arts staffing being three times the size of the professional school's staffing. While such demand-based hiring helps promote consistent academic classroom intensity, its impact on the resources available for faculty-based services, such as advising, is insidious. While the faculty of each major will have only five students to provide out-of-class enrichment activities to, there will be three times the number of liberal arts faculty to serve those students.

Clearly, the resources available to dedicate to out-of-class faculty-provided services will not be consistent across the campus. Even though students pay the same tuition, the college dedicates different amounts of resources to the non-classroom activity portion of each student's education. The professional school will have fewer faculty resources available to provide the enhancements that have been identified as critical to their majors' educational experiences (Astin, 1984; Pascarella, 1980). Of course, the school of liberal arts could choose to dedicate faculty at the same proportion to provide out-of-classroom services as the professional school. While this would equalize the resources provided for such services, the authors suspect that the overall quality would decline, since such services require faculty interaction with students. Given the critical nature of such services to student education, that does not appear to be an optimal solution.

\section{The Full Model}

To model this relationship for an actual college that hires faculty to accommodate demand-based scheduling, the authors initially make a series of assumptions that can later be loosened. Let $A \%$ represent the percent of the total student body (SB) majoring in liberal arts and $B \%$ the percent majoring in the business. Then the authors can represent the number of liberal arts majors (AM) and the number of business school majors (BM) as: 
Also assume that to maintain a desired level of academic intensity in the classroom, faculty are hired when SCPF (the Student Credit hours Per full-time Faculty member) reach a target level. If students take, on average, $S C$ credit hours per semester, with business students taking a liberal arts core equal to (1-X) \% of their credits while arts students take no business courses, the number of faculty necessary to maintain the desired level of academic intensity in liberal arts and business can be expressed as $F_{a}$ and $F_{b}$, where:

$F_{a}=[(A M * S C)+(B M * S C *(1-X))] / S C P F$

Equation 1.1a

$\left.F_{b}=(B M * S C * X) / S C P F\right)$

Equation $1.1 \mathrm{~b}$

To obtain the number of majors per faculty for each school, the authors divide $A M$ and $B M$ and by equation 1.1a and 1.1b, respectively. After simplifying, this yields the final result of equations 1.2.

$$
\begin{aligned}
& \frac{A M}{F_{a}}=\frac{A M * S C P F}{((S B \quad(X * B M)) * S C} \\
& \frac{B M}{F_{b}}=\frac{S C P F}{S C * X}
\end{aligned}
$$

Equation 1.2a

Equation $1.2 \mathrm{~b}$

While equations $1.2 \mathrm{a}$ and $1.2 \mathrm{~b}$ represent the majors per faculty member, if students are to be advised by the faculty within their own schools, it also represents the minimum number of advisees per faculty member. An interesting insight derived from equation $1.2 \mathrm{~b}$ is that if liberal arts students take no business courses, the ratio of business majors to business faculty depends solely on factors that do not vary as the size of the professional school grows.

Table 1 presents the student majors per faculty that results for a college with a student body $(S B)$ of 3,000, a target average class size of 25 students (equal to 300 credit hours per faculty member [SCPF] for faculty teaching four 3-credit courses) and students credit hours per semester (SC) equal to 15. In addition, it was assumed that all students of the college take a liberal arts core equal to $40 \%$ of their credits and liberal arts students take $0 \%$ of their credits in the professional school.

Table 1: Staffing And Access To In-Major Faculty For Business

\begin{tabular}{|c|c|c|c|c|c|}
\hline $\begin{array}{c}\text { \% Business } \\
\text { Students (1) }\end{array}$ & $\begin{array}{c}\text { Ratio Of Arts To } \\
\text { Business Faculty (2) }\end{array}$ & $\begin{array}{c}\text { Students Per } \\
\text { Business Faculty (3) }\end{array}$ & $\begin{array}{c}\text { Students Per Arts } \\
\text { Faculty (4) }\end{array}$ & $\begin{array}{l}\text { \# Business } \\
\text { Faculty (5) }\end{array}$ & $\begin{array}{c}\text { \# Arts } \\
\text { Faculty (6) }\end{array}$ \\
\hline 5 & 32.33 to 1.0 & 33.33 & 19.59 & 4.50 & 145.50 \\
\hline 15 & to 1.0 & 33.33 & 18.68 & 13.50 & 136.50 \\
\hline 25 & to 1.0 & 33.33 & 17.65 & 22.50 & 127.50 \\
\hline 35 & to 1.0 & 33.33 & 16.46 & 31.50 & 118.50 \\
\hline 45 & to 1.0 & 33.33 & 15.07 & 40.50 & 109.50 \\
\hline 50 & to 1.0 & 33.33 & 14.29 & 45.00 & 105.00 \\
\hline 55 & to 1.0 & 33.33 & 13.43 & 49.50 & 100.50 \\
\hline 65 & to 1.0 & 33.33 & 11.48 & 58.50 & 91.50 \\
\hline 75 & to 1.0 & 33.33 & 9.09 & 67.50 & 82.50 \\
\hline 85 & to 1.0 & 33.33 & 6.12 & 76.50 & 73.50 \\
\hline 95 & to 1.0 & 33.33 & 2.33 & 85.50 & 64.50 \\
\hline 100 & to 1.0 & 33.33 & 0.00 & 90.00 & 60.00 \\
\hline
\end{tabular}
And Liberal Arts Students When A General Education Requirement Is Present ${ }^{1}$ 
The results presented in column 4 of Table 1 suggest that in addition to always having greater access than business students to their school's faculty, access for arts students grows if the School of Business grows. This occurs since the general education requirements of the college ensures that the number of liberal arts faculty will not decline rapidly even if the number of liberal arts majors declines.

The pervasiveness of the General Education requirement's impact on faculty resources is clearly observable in the bottom rows of Table 1. For the situation where the business school has grown to be $85 \%$ or more of the college, liberal arts majors have access to highly intensive faculty service while business majors continue to experience less access to faculty, an intensity of one faculty member for each 33 students. Even if the business school enrolls $100 \%$ of the student body, the general education requirement will ensure that the ratio of arts to business faculty does not fall below .67 to 1 . For schools that retain their liberal arts designation by restraining business enrollment below 50\%, the school of liberal arts will always have more faculty resources to dedicate to provide the non-classroom components of their majors' education.

\section{The Impact Of Liberal Arts Students In Business Courses}

While general education requirements usually do not include business courses (Vars, 1982), liberal arts students often take some of their electives in the business school. Therefore, Table 2 was generated assuming that business students take $60 \%$ of their credits within the business school (a $40 \%$ general education requirement) and liberal arts students elect to take $10 \%$ of their credits within the business school.

In this case, the number of business credit hours taught will be dependent both on the number of business majors as well as the business credits taken by arts majors. As can be seen through comparing column 2 in Tables 1 and 2, the enrollment of liberal arts students in business courses will have a significant impact on the liberal arts to business faculty ratio and thus enhancing the ability of business faculty to provide majors with out-of-class services.

Table 2: Staffing And Access To In-Major Faculty For Business And Liberal Arts Students When Arts Students Take Business Courses ${ }^{1}$

\begin{tabular}{|c|c|c|c|c|c|c|c|c|}
\hline $\begin{array}{r}\% \text { Business } \\
\text { Students (1) } \\
\end{array}$ & $\begin{array}{r}\text { Ratio ( } \\
\text { Business } \\
\end{array}$ & $\begin{array}{l}\text { Arts To } \\
\text { culty (2) }\end{array}$ & $\begin{array}{r}\text { Stud } \\
\text { Business } \\
\end{array}$ & $\begin{array}{l}\text { S Per } \\
\text { culty (3) }\end{array}$ & $\begin{array}{r}\text { Studen } \\
\text { Fac }\end{array}$ & $\begin{array}{l}\text { er Arts } \\
(4)\end{array}$ & $\begin{array}{c}\text { \# Business } \\
\text { Faculty (5) } \\
\end{array}$ & \# Arts Faculty (6) \\
\hline 5 & 7.00 & to 1.0 & 8.00 & to 1.0 & 21.71 & to 1.0 & 18.75 & 131.25 \\
\hline 15 & 4.71 & to 1.0 & 17.14 & to 1.0 & 20.61 & to 1.0 & 26.25 & 123.75 \\
\hline 25 & 3.44 & to 1.0 & 22.22 & to 1.0 & 19.35 & to 1.0 & 33.75 & 116.25 \\
\hline 35 & 2.64 & to 1.0 & 25.45 & to 1.0 & 17.93 & to 1.0 & 41.25 & 108.75 \\
\hline 45 & 2.08 & to 1.0 & 27.69 & to 1.0 & 16.30 & to 1.0 & 48.75 & 101.25 \\
\hline 50 & 1.86 & to 1.0 & 28.57 & to 1.0 & 15.38 & to 1.0 & 52.50 & 97.50 \\
\hline 55 & 1.67 & to 1.0 & 29.33 & to 1.0 & 14.40 & to 1.0 & 56.25 & 93.75 \\
\hline 65 & 1.35 & to 1.0 & 30.59 & to 1.0 & 12.17 & to 1.0 & 63.75 & 86.25 \\
\hline 75 & 1.11 & to 1.0 & 31.58 & to 1.0 & 9.52 & to 1.0 & 71.25 & 78.75 \\
\hline 85 & 0.90 & to 1.0 & 32.38 & to 1.0 & 6.32 & to 1.0 & 78.75 & 71.25 \\
\hline 95 & 0.74 & to 1.0 & 33.04 & to 1.0 & 2.35 & to 1.0 & 86.25 & 63.75 \\
\hline 100 & 0.67 & to 1.0 & 33.33 & to 1.0 & 0.00 & to 1.0 & 90.00 & 60.00 \\
\hline
\end{tabular}

Table 2 also demonstrates that as the percent of students enrolled in the business school increases, the ratio of business majors to faculty will continue to rise. It is expected that such a decline in the time available to individually attend to each student will generate a situation where student satisfaction with business faculty services will decline relative to the satisfaction of liberal arts students. This occurs since increases in business enrollment will cause the number of business faculty to rise, but not as fast as the number of students. Simultaneously, the number of courses taken by business students outside their school causes the quantity of liberal arts faculty to rise, partially offsetting the effect of the declining number of arts majors on staffing. In addition, the impact of the liberal arts students taking business courses is reduced as the arts school declines in size. 
A comparison of columns 4 in Tables 1 and 2 also suggests that as the percent of business students increases, the number of faculty per student major in liberal arts move toward similar values, regardless of the amount of business courses taken by arts students. This is because as the business school grows (and the number of liberal arts students declines), it is the business students' general education requirements that most strongly impact the level of liberal arts staffing.

\section{The Impact Of Adjucnt Faculty}

Within the academic community, there has been an increased utilization of adjunct faculty as administrators attempt to both lower costs and meet student demand for specialized course offerings (Jacoby, 2006; Adamowicz, 2007). Since adjunct faculty duties are generally limited to the classes they teach, their presence will have an impact on the faculty-provided services. AACSB identifies such faculty as those not significantly involved in the life of the college. This is in stark contrast with participating faculty members who are involved in other activities, such as service and advising in addition to their teaching (AACSB, 2013). To quantify the impact of such faculty on the ability to provide services, Table 3 was generated retaining the same demographic and curricular assumptions used for Table 2. In addition, it was assumed that adjunct faculty teach 68 classes in each school. This is the equivalent to 17 full-time faculty positions.

A comparison of Tables 2 and 3 indicates that the ratio of full-time liberal arts to business faculty does not change. However, the number of students per faculty member varies significantly, suggesting that the use of adjunct faculty can have a significant impact on out-of-class services, such as advising. For low levels of business enrollment, the use of adjuncts places a significant burden on business faculty who are already experiencing understaffing of non-classroom activities. However, as the relative size of the business school grows, the impact of adjuncts decrease if the number of courses they teach remains constant. For the liberal arts, the use of adjuncts has only minor impacts when the school is large, but it grows if business expands. An examination of Table 3 also suggests that the use of adjunct faculty in the liberal arts will offset some of the benefits that arise from the general education requirement's impact on staffing. However, the use of adjunct faculty will only significantly reduce the ability of liberal arts faculty to interact one on one with student majors if the school of liberal arts is small relative to the business school. This will occur since the general education requirement ensures that the liberal arts school is better staffed for out-of-classroom activities performed by full-time faculty.

Table 3: Staffing And Access To In Major Faculty

For Business And Liberal Arts Students When Adjunct Faculty Are Present ${ }^{1}$

\begin{tabular}{|c|cc|cc|cc|c|c|}
\hline $\begin{array}{c}\text { \% Business } \\
\text { Students }\end{array}$ & \multicolumn{2}{|c|}{$\begin{array}{c}\text { Ratio Of Arts To } \\
\text { Business Faculty }\end{array}$} & $\begin{array}{c}\text { Students Per Full- } \\
\text { Time Business Faculty }\end{array}$ & $\begin{array}{c}\text { Students S Per Full- } \\
\text { Time Arts Faculty }\end{array}$ & $\begin{array}{c}\text { Full-Time } \\
\text { Business Faculty }\end{array}$ & $\begin{array}{c}\text { Full-Time Arts } \\
\text { Faculty }\end{array}$ \\
\hline 5 & 7.00 & to 1.0 & 85.71 & to 1.0 & 24.95 & to 1.0 & 1.75 & 114.25 \\
\hline 15 & 4.71 & to 1.0 & 48.65 & to 1.0 & 23.89 & to 1.0 & 9.25 & 106.75 \\
\hline 25 & 3.44 & to 1.0 & 44.78 & to 1.0 & 22.67 & to 1.0 & 16.75 & 99.25 \\
\hline 35 & 2.64 & to 1.0 & 43.30 & to 1.0 & 21.25 & to 1.0 & 24.25 & 91.75 \\
\hline 45 & 2.08 & to 1.0 & 42.52 & to 1.0 & 19.58 & to 1.0 & 31.75 & 84.25 \\
\hline 50 & 1.86 & to 1.0 & 42.25 & to 1.0 & 18.63 & to 1.0 & 35.50 & 80.50 \\
\hline 55 & 1.67 & to 1.0 & 42.04 & to 1.0 & 17.59 & to 1.0 & 39.25 & 76.75 \\
\hline 65 & 1.35 & to 1.0 & 41.71 & to 1.0 & 15.16 & to 1.0 & 46.75 & 69.25 \\
\hline 75 & 1.11 & to 1.0 & 41.47 & to 1.0 & 12.15 & to 1.0 & 54.25 & 61.75 \\
\hline 85 & 0.90 & to 1.0 & 41.30 & to 1.0 & 8.29 & to 1.0 & 61.75 & 54.25 \\
\hline 95 & 0.74 & to 1.0 & 41.16 & to 1.0 & 3.21 & to 1.0 & 69.25 & 46.75 \\
\hline
\end{tabular}

\section{Advising Quality And The Failure Of Satisfaction Surveys}

The model presented above demonstrates that because of a core curriculum, if a target class size is maintained for either educational or marketing purposes, business schools will have relatively fewer faculty to provide quality out-of-classroom interactions with students compared to the liberal arts school. Since colleges have 
been adopting a service marketing perspective, the authors now turn to examine how staffing levels bias the interpretation of surveys which attempt to measure student satisfaction with faculty-based services, such as advising. To examine this issue, actual survey data collected from graduating seniors at a liberal arts college is used.

Table 4: Advising Quality Survey

\begin{tabular}{|l|c|c|c|}
\hline \multicolumn{1}{|c|}{ Decision Units } & $\begin{array}{c}\text { Input } \\
\text { Faculty }\end{array}$ & $\begin{array}{c}\text { Output } \\
\text { \# Advised }\end{array}$ & $\begin{array}{c}\text { Output } \\
\text { Composite Ratings }\end{array}$ \\
\hline Arts & 76 & 1292 & 3.41 \\
\hline Business & 39 & 1143 & 3.03 \\
\hline Science & 42 & 624 & 3.69 \\
\hline
\end{tabular}

Presented in Table 4 are the results from a survey of graduating seniors at a college which has demographics similar to those identified in the tables above. The main difference here is that this college is comprised of three schools. While this data is from one year, annual surveys have consistently generated this pattern. A cursory examination of this table suggests that student satisfaction with business school advisement quality falls significantly below that of the other schools. The results have been used to infer that advising by business faculty is of lower quality. However, an examination of column 2 and 3 of Table 4 indicates that the college, as a bi-product of its staffing policy, has allocated significantly fewer faculty resources to business advisement relative to the number of students advised. In order to gain a quantitative measure of the impact of this disparity, the authors will utilize Data Envelopment Analysis.

"DEA is a method for calculating the relative effectiveness of a set of organizations that possess some common functional elements, but whose efficiency may vary due to internal differences" (Laguna \& Marklund, 2005). In the case of this survey data, the common functional element is a faculty-based advising system and the internal differences are the resources (faculty) available to advise in each school of the college. For purposes of this demonstration, there are three processes (advising within each school) that yield advised students' survey results. DEA will be used to demonstrate how failure to adjust for differences in resources may be impacting the authors' perception of the results.

Table 5 displays the efficiency of each school along with a peer group for the relatively inefficient processes. Thus, the Liberal Arts school's advising is identified by DEA analysis to be inefficient with a relative efficiency of only .5801, a value found by solving the linear programming formulation of the DEA ratio model. Business is found to be Liberal Art's peer group process since both are high throughput processes and it identifies Business advising as the efficient process. This is because the School of Business generates a high throughput of students, using relatively few resources, with only a modest decline in satisfaction. On the other hand, science advising is an efficient process since it is a high resources use, high satisfaction, low throughput process.

Table 5: Advising Ratings: Efficiency

\begin{tabular}{|l|c|c|}
\hline \multicolumn{1}{|c|}{ Decision Making Unit } & Efficiency & Peer Group \\
\hline Liberal Arts & 0.5801 & Business \\
\hline Business & 1.0000 & \\
\hline Science & 1.0000 & \\
\hline
\end{tabular}

Table 6 shows the target values for relatively inefficient processes. Examining the liberal arts advising process, and knowing from Table 5 that its peer group is Business, DEA analysis indicates that the liberal arts school would have to both reduce the number of advisers to 44 and maintain their same ratings to achieve the same efficiency as the Business School. Thus, this simple DEA model indicates that student satisfaction with liberal arts advising is low relative to the resources dedicated to it. Meanwhile, student apparent dissatisfaction with business advising is an indicator of the low level of resources allocated to business school advising by the college.

Table 6: Advising Ratings: Targets

\begin{tabular}{|l|c|c|c|}
\hline Decision-Making Unit & Faculty & Advised & Ratings \\
\hline Arts & 44.0840 & 1292.0000 & 3.4250 \\
\hline
\end{tabular}




\section{SUMMARY AND CONCLUSIONS}

This analysis suggests that one should expect both the actual and perceived quality of faculty generated out-of-class services to be lower in a college's professional schools versus the schools that provide the college's general education courses. When staffing is driven by student credit hours, a business school's full-time faculty will face a proportionately larger burden than their liberal arts school colleagues in serving their student majors. For faculty-centered advisement services, this will increase the likelihood of both advisement burnout and a reluctance to participate in advising. The use of adjuncts within the classroom will only worsen this situation. Thus, one should expect both the students and faculty of professional schools to be relatively dissatisfied with out-of-class services delivered by faculty. This is because the college is allocating insufficient resources toward these activities within the professional school versus the schools which provide college core courses. In addition, the use of DEA analysis on the survey data presented above demonstrates that one needs to be careful with how such surveys are interpreted. Once adjustments are made for resources dedicated to an activity, the authors' conclusions may be significantly altered.

The authors believe that this analysis indicates that in order for a college's professional school's students to have the opportunity to receive the same quality of advisement and other faculty generated out-of-class services as their non-professional school peers, additional resources are necessary. Possible uses of these resources include lowering the professional school's student to faculty ratio below that of the college's liberal arts school or providing such services with non-faculty resources. For advising, the use of non-faculty advisers within the professional schools would allow for both the equalization of perceived advisement quality, as well as offer opportunities to standardize actual quality. Given the critical role of such services to student satisfaction, academic achievement, and degree completion, the allocation of funds for such services appears to be clearly warranted.

\section{AUTHOR INFORMATION}

Dr. Thomas J. Kopp has been a faculty member at Siena College for over 30 years. He has served on numerous campus wide committees, key committees within the school as it sought and maintained AACSB accreditation, and has served numerous terms as Chair of the Finance Department in the School of Business. Dr. Kopp is also recognized as a rigorous and well respected classroom professor. Finally, he has been cited by the School of Business for his outstanding intellectual contribution activities by receiving an excellence in research award in recognition of his wide array of conference presentations, papers and journal publications. Email: Kopp@ @iena.edu.

Professor Joseph L. Rosetti is beginning his $30^{\text {th }}$ year as a faculty member at Siena College. He has served on key campus-wide governance committees, as well as campus and School of Business curricular committees, and has served in a variety of administrative capacities, including Assistant Vice President of Academic Affairs. Finally, Professor Rosetti has been cited by the School of Business for his outstanding teaching by receiving an excellence in teaching award in recognition of his outstanding classroom instruction and curricular development activities. His intellectual contribution activities are pedagogy-focused conference presentations, papers and journal publications. Email: Rosetti@siena.edu.

\section{REFERENCES}

1. Adamowicz, C. (2007, November/December). Academe Online. Retrieved February 7, 2008, from www.auap.org.

2. Association to Advance Collegiate Schools of Business. (2013). 2013 Business Accreditation Standards, Standard 5 Faculty Sufficiency and Deployment.

3. Astin, A. W. (July 1984). "Student Involvement: A Development Theory for Higher Education," Journal of College Student Personnel, 297-308.

4. Belcheir, Marcia J. (2000). "An Evaluation of Advising Programs. Research Report," Boise State University, Office of Institutional Assessment.

5. Brocklehurst, N. (1980). College Enrollment in the 1980's. Academe: Bulletin of the AAUP, 66(1), 16-18.

6. Byrd, Marquita L. (1994). “Academic Advising Ain't What it Used to Be: Strangers in the University," Paper presented at the Annual Meeting of the National Academic Advising Association (18 ${ }^{\text {th }}$, Las Vegas, 
NV, October 9-12).

7. Glennen, R. E. (1975). Intrusive College Counseling. College Student Journal, 9(1), 2-4.

8. Glennen, R. E., Farren, P. J., \& Vowell, F. N. (1996). How advising and retention of students improves fiscal stability. NACADA Journal, 16(1), 38-41.

9. Gordon, Virginia. (2002). "Certification” Task Force Report. Presented to NACADA Board, September 13.

10. Gruber, Thorsten, Reppel, Alexander, \& Voss, Roediger. (2010). "Understanding the Characteristics of Effective Professors: The Student's Perspective.” Journal of Marketing for Higher Education, Vol. 20, No. 2, pp. 175-190.

11. Jacoby, D. (2006). Effects of Part-Time Faculty Employment on Community College Graduation Rates. Journal of Higher Education, 77, 1081-1103.

12. Karrenbrock \& Joyce Associates (June 2001). "Factors Affecting Student Graduation Rates at California State University, Northridge," page 4. Consultants report of the University.

13. Kopp, T. J. \& Rosetti, J. L. (2009). "The Impact of Market Driven Staffing on Faculty Governance in a General Education Environment." Journal of the World Universities Forum, Vol. 2, No. 1, pp. 27-37.

14. Kopp, T. J. \& Rosetti, J. L. (Summer 2004). "Where is My Business Advisor? The Challenge of Advising Business Students in a Liberal Arts Setting." Journal of the Academy of Business Education, No. 5.

15. Krueger, Alan B. (February 2003). "Economic Considerations and Class Size," The Economic Journal, 113, pp. 34-63.

16. Laguna, Manuel, \& Marklund, Johan. (2005). Business Process Modeling, Simulation, and Design. Prentice Hall, N.J., pp. 392-408.

17. Mateo, Miguel, \& Fernandez, Juan. (October 1996). "Incidence of Class Size On The Evaluation Of University Teaching Quality," Educational and Psychological Measurement, Vol. 56 No. 5, pp. 771-778.

18. Ng, Irene \& Forbes, Jeannine. (2009). "Education as Service: The Understanding of University Experience Through the Service Logic." Journal of Marketing for Higher Education, Vol. 19, No 1, pp 38-64.

19. Pascarella, E.T. (1980). "Student-Faculty Informal Contact and College Outcomes." Review of Educational Research, 50, pp. 545-95.

20. Slaughter, S. \& Rhoades, G. (2004). Academic capitalism and the new economy markets, state, and higher education. Baltimore: Johns Hopkins University Press.

21. Vars G. F. (1982). "Designs for General Education: Alternative Approaches to Curricular Integration." Journal of Higher Education, Vol. 53, No. 2, pp. 216-226. 